Vol. 3 | No. 1 | 2022 | Hal. 25-29

\title{
PENGEMBANGAN SISTEM PEMASARAN MELALUI MEDIA ONLINE BAGI UMKM BATIK TULIS DI MASA PANDEMI COVID-19
}

\author{
Ratna Tri Hardaningtyas*, Ahmad Rifqi Mubarok \\ Fakultas Ekonomi dan Bisnis, Universitas Islam Malang \\ *korespondensi email: ratnatyas@unisma.ac.id
}

\begin{abstract}
ABSTRAK
Usaha Mikro, Kecil dan Menengah (UMKM) telah menyebar di seluruh wilayah indonesia. Salah satu UMKM yang khas di Desa Argotirto yaitu batik tulis. Karena pandemi, penjualan dari batik ini sempat vakum selama beberapa bulan. Oleh karena itu pemberdayaan UMKM Batik Tulis sangat di butuhkan guna untuk mengembangkan usaha Batik Tulis di Desa Argotirto ini. Di era pandemi masyarakat harus bisa memanfaatkan UMKM yang ada, mengolahnya serta memasarkan dalam media offline atau online agar ekonomi masyarakat bisa bertambah khususnya di era pandemi seperti sekarang ini. Salah satu upaya yang bisa di lakukan adalah dengan memberdayakan UMKM dengan cara memberi inovasi motif batik tulis agar dapat lebih update motif sehingga konsumen mudah tertarik, serta membantu pemasaran di media massa karena jangkauan pasarnya lebih luas dan praktis di bandingkan brosur dan door to door. Diharapkan berbagai kegiatan yang di lakukan dapat menambah wawasan, ilmu serta membantu majunya UMKM Batik Tulis, sehingga dapat membantu ekonomi masyarakat.
\end{abstract}

Kata Kunci: pemberdayaan; batik tulis; inovasi

\section{PENDAHULUAN}

Desa Argotirto adalah salah satu desa yang berada di Kecamatan Sumbermanjing Wetan, Kabupaten Malang, Provinsi Jawa Timur. Desa Argotirto tanahnya cukup subur sehingga banyak sekali yang bertani kopi, tebu, sawah, pisang, jagung, ketela hingga ke tanaman cokelat juga banyak di daerah ini, maka dari itu motif Batik Tulis UMKM di desa Argotirto terkenal dengan motif kopi dan tebunya. UMKM ini cukup membantu masyarakat di masa pandemi ini. Definisi UMKM menurut Anggraeni et al. (2013) usaha kecil adalah usaha produktif milik warga negara Indonesia, yang berbentuk badan usaha orang perorangan, badan usaha yang tidak berbadan hukum, atau badan usaha berbadan hukum.

Batik tulis ialah dari hasil proses produksi batik dengan teknis pengerjaan motifnya ditulis langsung dengan manual oleh pembatik (Moerniwati, 2020). Untuk menulisnya, dapat memakai canting yang dibuat dari tembaga yang diperlengkapi gagang dari bambu. Ujung dari canting punya lubang yang berbagai macam, hingga dapat mengatur ukuran motifnya. Disamping itu, ada bak penampung canting yang diberi nama dengan nyamplung. Alat ini berisi cairan malam atau pewarna, bergantung dari tehnik batik yang nanti akan dipakai. Batik tulis warna adalah tehnik batik tulis dengan mentuliskan cairan malam lewat canting tulis (Probosiwi \& Febrian, 2021).

Batik tulis dibuat secara manual menggunakan tangan dengan alat bantu canting untuk menerankan malam pada corak batik. Pembuatan batik tulis membutuhkan kesabaran dan 
ketelatenan yang tinggi karena setiap titik dalam motif berpengaruh pada hasil akhirnya. Motif yang dihasilkan dengan cara ini tidak akan sama persis. Kerumitan ini yang menyebabkan harga batik tulis sangat mahal. Jenis batik ini dipakai raja, pembesar keraton, dan bangsawan sebagai simbol kemewahan (Riadi, 2019).

Berdasarkan observasi yang telah dilakukan terdapat beberapa masalah yang di keluhkan oleh pelaku UMKM (Usaha Mikro Kecil Menengah) batik tulis di desa Argotirto ini, salah satunya adalah kurangnya pembeli serta kurangnya pemasaran offline maupun online sehingga masyarakat luas pun belum sepenuhnya mengenal batik ini yang berakibat juga pada penjualannya nanti. Di masa pandemi ini UMKM Batik Tulis Argotirto sempat mengalami Vakum sekitar 4-5 bulan setelah menerima pesanan sekitar 30 lebih batik dimana batik tersebut di pakai untuk perangkat desa, guru sekolah serta pegawai bank di daerah sekitar.

Pemberdayaan UMKM ini bertujuan untuk meningkatkan ekonomi masyarakat apalagi di era pandemi ini, dengan memanfaatkan media massa di harapkan dapat menambah jangkauan pembeli serta di harapkan dapat menarik banyak pembeli dari berbagai macam kalangan. Globalisasi menjadi tantangan bagi Usaha Kecil dan Menengah (UKM) untuk terus bertahan. Teknologi Informasi terutama media sosial menawarkan manfaat bagi UKM untuk meningkatkan pemasarannya (Pramudita et al., 2022; Rachmadi et al., 2021).

Dunia sedang mengalami Pandemi Covid-19 termasuk Indonesia. Himbauan untuk mencegah mata rantai penyebaran virus ini mengharuskan masyarakat untuk berdiam diri dirumah. Hal ini berdampak pada ketidakstabilan ekonomi dan salah satu yang terdampak adalah UMKM. Untuk itu diperlukan strategi bertahan bagi UMKM untuk dapat terus mempertahankan bisnisnya di tengah pandemi ini.

Krisis yang menimpa Indonesia tahun 1997 diawali dengan krisis nilai tukar rupiah terhadap dollar AS dan krisis moneter yang berdampak pada perekonomian Indonesia yakni resesi ekonomi. Hal ini merupakan pelajaran yang sangat penting untuk kembali mencermati suatu pembangunan ekonomi yang benar-benar memiliki struktur yang kuat dan dapat bertahan dalam situasi apapun (Hasan, 2018). Dengan adanya pembelajaran seperti ini di harapkan masyarakat dapat mengambil hikmah dan selalu tetap kokoh dalam mendirikan UMKM. Apalagi jumlah UMKM di Indonesia mencapai 64,19 juta, dengan komposisi Usaha Mikro dan Kecil (UMK) sangat dominan yakni 64,13 juta $(99,92 \%)$ dari keseluruhan sektor usaha. Kelompok ini pula yang merasakan imbas negatif dari pandemi Covid-19. Dalam situasi krisis ekonomi seperti ini, sektor UMKM sangat perlu perhatian khusus dari pemerintah karena merupakan penyumbang terbesar terhadap PDB dan dapat menjadi andalan dalam penyerapan tenaga kerja, mensubtitusi produksi barang konsumsi atau setengah jadi. Apalagi di tengah sentimen positif bahwa kondisi perekonomian tahun ini akan membaik membuat sektor UMKM harus bisa memanfaatkan momentum pertumbuhan ekonomi saat ini untuk dapat pulih.

\section{METODE}

Kegiatan pemberdayaan UMKM kepada pelaku usaha Batik Tulis dilaksanakan di Desa Argotirto Kecamatan Sumbermanjing Wetan Kabupaten Malang. Kegiatan ini dilakukan oleh Pelatih Batik Tulis di Desa Argotirto serta KSM-Tematik kelompok 38 yang di mulai dengan diskusi terkait rencana kegiatan pemberdayaan serta pemanfaatan media online untuk pemsaran UMKM (Usaha Mikro Kecil Menengah) batik tulis.

Kegiatan ini dilakukan untuk membantu berinovasi serta memanfaatkan media massa sebagai alat pemasaran serta penjualan Batik Tulis guna untuk membantu ekonomi masyarakat di masa pandemi COVID-19 ini. Kegiatan ini meliputi survey lokasi, diskusi, dan praktek. Adapun tahapan yang dilakukan dalam pelaksanaan sebagai berikut: 


\section{Survey Lokasi}

Survey Lokasi yang dilakukan di Desa Argotirto adalah untuk menentukan kondisi UMKM Batik Tulis serta melihat kelemahan dan kekurangannya, agar kegiatan yang dilakukan oleh KSMTematik Kelompok 38 tepat dan mudah.

\section{Sosialisasi}

Sosialisasi yang dilakukan di rumah yang di tempati sebagai UMKM. Kegiatan ini juga melibatkan masyarakat desa serta pelaku UMKM.

\section{Pemberian Materi}

Pemberian Materi dilakukan oleh KSM-Tematik kepada pelaku UMKM. Adapun pemberian materi ini berupa (1) Peningkatan semangat kepada semua pelaku UMKM (2) Peningkatan pengetahuan kepada pelaku UMKM terkait fungsi media online untuk penjualan dan pemasaran guna untuk membantu ekonomi di masa pandemi ini.

\section{Evaluasi Kegiatan}

Evaluasi Kegiatan dilakukan untuk menentukan tingkat keberhasilan dalam memanfaatkan media massa sebagai alat pemasaran dan penjualan.

\section{Teknik Pengumpulan Data}

Pengumpulan Data dilakukan dengan cara observasi secara langsung serta memberikan pertanyaan kepada pelaku usaha UMKM Batik Tulis guna untuk memberdayakan UMKM serta memasarkannya di media online.

\section{Teknik Analisis Data}

Analisis yang di lakukan berupa pendekatan kualitatif dan kuantitatif. Pendektan kualitatif ini digunakan sebagai analisis hasil observasi pemahaman pelaku UMKM selama proses materi pemberdayaan UMKM serta memanfaatkan media online sebagai pmasaran dan penjualan, sedangkan pendekatan kuantitatif dilakukan untuk menganalisis data hasil pertanyaan yang di berikan oleh KSM-Tematik.

\section{HASIL DAN PEMBAHASAN}

Pelaksanaan program pemberdayaan serta pemanfaatan media online dalam pengembangan sistem pemasaran umkm (batik tulis) di masa pandemi covid-19 Di Desa Argotirto, Kecamatan Sumbermanjing Wetan, Kabupaten Malang ini dilaksanakan setelah dilakukannya pengamatan terhadap kondisi UMKM Batik Tulis ini. Ditemukan bahwa UMKM ini belum sepenuhnya memanfaatkan media online sebagai alat pemasaran sehingga penjualannya pun cukup sedikit. Pihak pelaku UMKM pun berkata bahwa kelemahan dari UMKM ini adalah pemasaran apalagi di bidang digital, serta karyawannya juga belum banyak yang mengenal media online sebagai alat untuk memasarkan dan menjual produk.

\section{Pembuatan Akun Sosial Media}

Kegiatan ini bertujuan ntuk membantu menambah jangkauan serta pemasaran di sektor UMKM dikarenakan keluhan dari pihak pelaku UMKM adalah berkaitan dengan pemasaran. Maka dari itu kami membuatkan akun sosial khusus guna untuk mengembangkan UMKM tersebut terlebih pada masa pandemi COVID-19. Akun yang di buat meliputi Facebook (Batik Tulis Argotirto) Shoope (batik tulis argotirto) Instagram (batik tulis argotirto). Karena tiga media inilah yang saat ini terbukti bisa menambah pemasaran menjadi luas dikarenakan tidak memerlukan biaya besar serta kesulitannya relatif kecil.

\section{Pengambilan Gambar}

Tujuan dari pengambilan gambar ini adalah guna untuk menguploadnya ke media sosial. Agar pembeli bersimpati serta tertarik untuk membeli Batik Tulis ini maka kami memperindah tempat yang di gunakan untuk pengambilan gambar. Penataan kain Batik Tulis pun di susun secara rapi sehingga proses pengambilan gambar menjadi mudah dan hasilnya bagus. 


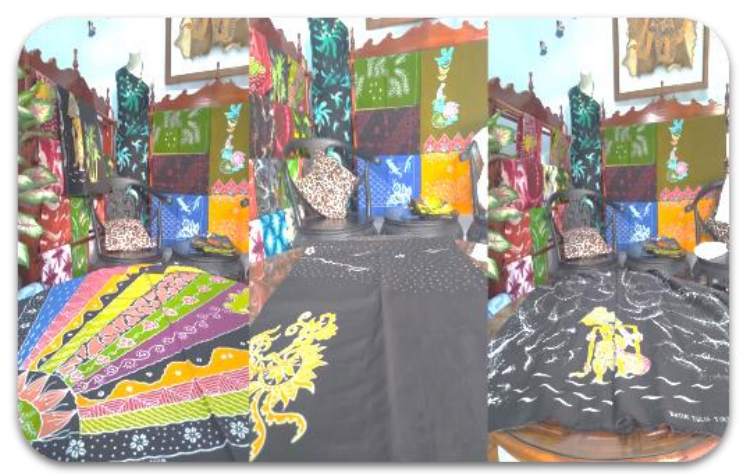

Gambar 1. Proses pengambilan gambar

\section{Pemasaran Serta Penataan Feeds Di Media Online}

Kegiatan ini bertujuan agar pelaku UMKM tidak kesulitan dalam hal pemasaran serta diharapkan bisa menambah jangkauan penjualan Batik Tulis ini. Di media sosial terkenal dengan feeds nya, apabila feeds tersebut jelek maka besar kemungkinan orang tidak mau stalking atau melihat barang-barang yang ada di akun tersebut, begitu juga sebaliknya apabila pengambilan gambar bagus serta feeds foto di akun dan captionnya dapat menarik perhatian publik maka besar kemungkinan orang akan tertarik untuk melihat, suka, dan akhirnya membeli apa yang anda jual di media online tersebut.

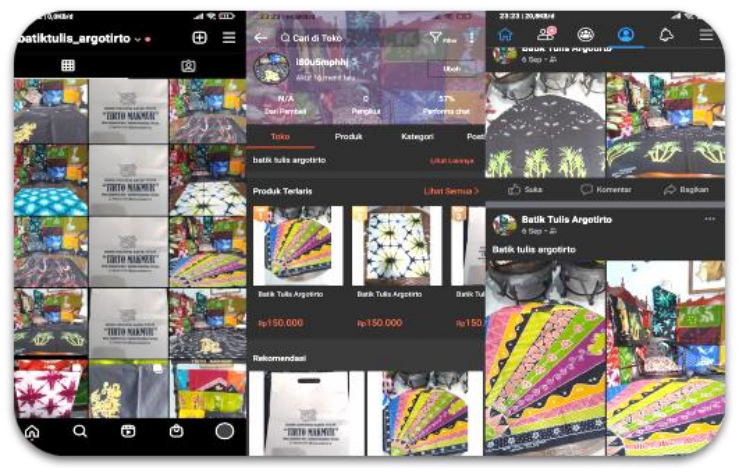

Gambar 2. Penataan Feeds untuk memasarkan di media sosial

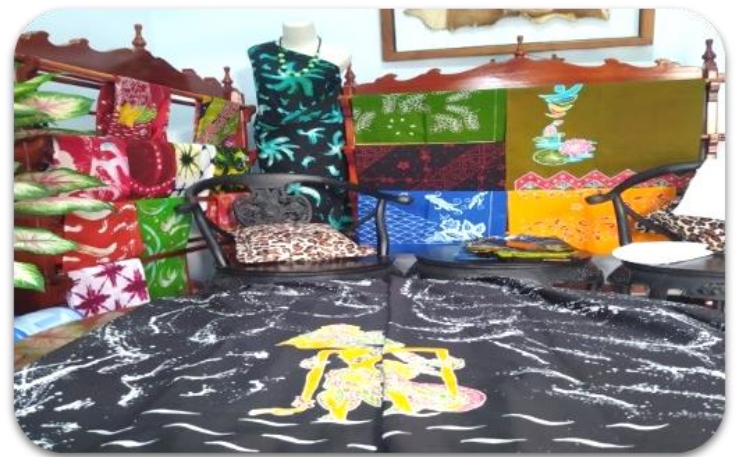

Gambar 3. Contoh Karya \& Melakukan diskusi dengan pemilik UMKM Batik Tulis "Argotirto"

\section{KESIMPULAN}

Pemasaran dan inovasi merupakan faktor utama dalam keberhasilan UMKM apalagi di masa pandemi Covid-19 ini segala UMKM cenderung menurun akibatnya adalah penjualan menurun, sulitnya mengembangkan usaha serta pemasaran. Namun beberapa masalah timbul dari sektor UMKM terlebih pada UMKM Batik Tulis Desa Argotirto, permasalahannya adalah antara lain; Pemasaran yang kurang, Sedikitnya pembeli, serta sulitnya mendapat 
simpati pembeli. Permasalahan terkait pemasaran ini adalah kurangnya pelaku UMKM dalam memanfaatkan media online dalam memasarkan produk di masa pandemi Covid-19. Media online adalah media yang sangat efektif digunakan untuk memasarkan dan menjual produk dikarenakan media online memiliki jangkauan yang luas serta banyak pengguna dari kalangan muda sampai tua. Di masa pandemi masyarakat lebih sering mengunjungi toko online daripada toko offline meskipun toko offline lebih menjanjikan atas keamanan serta kecocokan produk terhadap pembeli tetapi media online juga sangat berperan penting di masa pandemi ini dikarenakan masyarakat lebih sering tidak keluar rumah terkait PPKM, maka dari itu solusi dari masalah ini adalah salah satunya dengan memanfaatkan media online sebagai alat pemasaran serta penjualan di era pandemi ini, kegiatan yang dilakukan meliputi ; pembuatan akun, pengambilan gambar, penataan feeds serta pemasaran di dalam media online yang ada. Harapan kami dan juga pelaku UMKM adalah, dengan adanya pemasaran melalui media online UMKM Batik Ini lebih banyak dikunjungi pembeli serta banyak yang suka dan akhirnya memesan produk UMKM Batik Tulis ini.

\section{DAFTAR RUJUKAN}

Anggraeni, F. D., Hardjanto, I., \& Hayat, A. (2013). Pengembangan Usaha Mikro, Kecil, Dan Menengah (UMKM) Melalui Fasilitasi Pihak Eksternal Dan Potensi Internal (Studi Kasus pada Kelompok Tani "Emping Jagung" di Kelurahan Pandanwangi Kecamatan Blimbing, Kota Malang). Jurnal Administrasi Publik, 1(6), 1286-1295. http://administrasipublik.studentjournal.ub.ac.id/index.php/jap/article/view/195

Hasan, Z. (2018). Memori Krisis Moneter 1997/1998. DetikNews. https://news.detik.com/kolom/d-4032343/memori-krisis-moneter-19971998

Moerniwati, E. D. A. (2020). STUDI BATIK TULIS (Kasus di Perusahaan Batik Ismoyo Dukuh Butuh Desa Gedongan Kecamatan Plupuh Kabupaten Sragen). Art Educare, 1(1), 30-41. https://jurnal.uns.ac.id/jae/article/view/39281

Pramudita, B. A., Barri, M. H., Priharti, W., Rizal, A., Prihatiningrum, N., \& Hidayat, I. (2022). Pemanfaatan marketplace tokopedia untuk pengembangan usaha dalam meningkatkan perekonomian di tengah dampak pandemi covid-19. Jurnal Inovasi Hasil Pengabdian Masyarakat (JIPEMAS), 5(1), 80-91. https://doi.org/10.33474/jipemas.v5i1.11694

Probosiwi, \& Febrian, V. (2021). Mengambar Motif Batik di Jawa. Universitas Ahmad Dahlan.

Rachmadi, K. R., Jannah, M., \& Salsabilla, C. A. (2021). Pemanfaatan Mikro dan Marketing Guna Meningkatkan Perekonomian Desa di Masa Pandemi. Jurnal Pembelajaran $\begin{array}{llll}\text { Pemberdayaan } \quad \text { Masyarakat } & \text { (JP2M), }\end{array}$ https://doi.org/10.33474/jp2m.v2i3.13230

Riadi, M. (2019). Pengertian, Jenis, Motif dan Proses Pembuatan Batik. KajianPustaka.Com. https://www.kajianpustaka.com/2019/01/pengertian-jenis-motif-dan-prosespembuatan-batik.html 